\title{
Ortaokul Öğrencilerinde Olumlu Davranış Kazandırmaya Yönelik Psiko-Eğitim Programı ${ }^{1}$
}

\section{A Psycho-Education Program for Increasing Positive Behavior in Secondary School Students}

\author{
Ali Sonkur², Gökçen Aydın³ ${ }^{3}$ Aysel Kadı Dönder ${ }^{4}$
}

\author{
Anahtar Kelimeler \\ olumlu davranış \\ kazandırma \\ psiko-eğitim programı \\ ortaokul öğrencileri
}

\section{Keywords \\ increasing positive behavior \\ psycho-education program \\ secondary school \\ students}

Başvuru Tarihi/Received

23.06.2019

Kabul Tarihi /Accepted

16.11.2020
Öz

Öğrenciler okulda çeşitli sorunlar yaşamakta ve bu sorunlar onların akademik başarıları kadar sosyal ilişkilerini de etkilemektedir. İstenmeyen davranışlar olarak adlandırılan bu sorunların çeşitli nedenleri bulunmaktadır. Ancak alan yazına göre öğrenciden kaynaklı sorunlarla baş etmede empati kurma, iletişim becerilerini geliştirme ve duygularını ifade etme gibi becerilerin geliştirilmesi kullanılabilir. Bu doğrultuda, bu araştırmanın genel amacı, istenmeyen davranışlar sergileyen öğrenciler için “Olumlu Davranış Kazandırmaya Yönelik Psiko-Eğitim Programı” geliştirmek ve etkililiğini incelemektir. Araştırmanın katılımcılarını iki ayrı köy ortaokulunda 5. ve 6. sınıfa devam eden 9 kız, 11 erkek, toplam 20 öğrenci oluşturmaktadır. Veri toplama aracı olarak "İstenmeyen Öğrenci Davranışları Ölçeği”" kullanılmıştır. Psiko-eğitim programı, haftada bir saat olmak üzere 6 oturum şeklinde tasarlanmış ve iki ayrı köy okulunda uygulanmıştır. Elde edilen bulgular, “Olumlu Davranış Kazandırmaya Yönelik Psiko-Eğitim Programı”nın ardından öğrencilerin ön-test ve son-test puanları arasında anlamlı bir fark olduğunu, bu programın öğrencilerin istenmeyen davranışlarını azaltmayı olumlu yönde etkilediğini göstermiştir.

\section{Abstract}

Students experience various problems at schools and these problems might affect their academic success as well as their social relationships. There are several causes of these problems, called undesired behaviors. However, the literature indicates that skills such as empathy, developing communication skills or emotional awareness can be used to cope with studentrelated problems. In this respect, the general purpose of this study is to develop and examine the effectiveness of the "Psycho-Education Program For Increasing Positive Behavior" for students with undesired behaviors. The participants of the study consisted of 9 girls and 11 boys, totally 20 students attending 5th and 6th grades in two secondary schools in villages. "Undesirable Student Behaviors Scale" was used as data collection tool. The psycho-education program was designed as six sessions with one hour per week and implemented in two separate village schools. The findings showed that there was a significant difference between the pre-test and post-test scores of the students following the psycho-education program, and this program positively affected reducing the undesired student behaviors.

\footnotetext{
${ }^{1}$ Bu araştırma, 21. Uluslararası Psikolojik Danışma ve Rehberlik (PDR) Kongresi'nde (Antalya, 2019) sözel bildiri olarak sunulmuştur.

${ }^{2}$ Sorumlu Yazar, Doktora Öğrencisi, Hasan Kalyoncu Üniversitesi, Rehberlik ve Psikolojik Danışmanlık Anabilim Dalı, Gaziantep, TÜRKiYE; https://orcid.org/00000001-9651-8231, alisonkur02@gmail.com

${ }^{3}$ Dr. Öğr. Üy., Hasan Kalyoncu Üniversitesi, Eğitim Fakültesi, Rehberlik ve Psikolojik Danışmanlık Anabilim Dalı, Gaziantep, TÜRKiYE; https://orcid.org/0000-00030781-7817, gokcenaydn@gmail.com

${ }^{4}$ Yüksek Lisans Öğrencisi, Hasan Kalyoncu Üniversitesi, Rehberlik ve Psikolojik Danışmanlık Anabilim Dalı, Gaziantep, TÜRKiYE; https://orcid.org/0000-0002-0487$\underline{6830}$ kadiaysel@gmail.com
} 

Extended Abstract

\section{Introduction}

Students may experience various problems at schools, which affects their academic achievement as well as their social relationships. For example, students may sometimes find it difficult to establish positive relationships at schools and may even have to endure bad conditions if they do not want. In addition, being unaware of feelings and not knowing how to control them, not being able to distinguish their feelings and thoughts, and not knowing how to be respectful to themselves and others can cause various problems in the school climate. The literature points that these situations are defined as undesired student behaviors. There are several reasons of undesired behaviors like problems related to family, students, or teachers, financial problems, etc. The literature indicates that problems related to students can be changed in a positive way by emphasizing empathy and increasing awareness. Although research has been conducted to determine the undesired student behaviors, it is seen that there is a small number of experimental studies aiming to change these behaviors in a positive way. In this respect, the purpose of this study is to develop a psycho-education program called "Psycho-Education Group for Increasing Positive Behavior" for students who exhibit undesired behaviors at village secondary school with low socio-economic level, and to examine its effectiveness.

\section{Method}

In this study, weak experimental design was used. The participants of the study consisted of 20 students attending 5 th and 6 th grades at two secondary schools in villages. As data collection instrument, "Undesirable Student Behaviors Scale" was utilized. After obtaining the necessary permissions, the scale was applied to the participants as a pre-test and the students with the lowest score from the pre-test were identified and included in the 6-week psycho-education group for increasing positive behavior. The program was prepared and well-structured by the researchers in the light of the literature and implemented in two separate village schools. There were structured six sessions, each lasted one hour. After the application, the scale was applied again as post-test and the pretest-post-test scores of the participants were compared. The quantitative data were tested with Wilcoxon Signed Ranks Test.

\section{Result and Discussion}

The findings of the study revealed that there was a significant difference between the pre-test and post-test scores of the students following the psycho-education program for increasing positive behavior, and this program positively affected reducing the undesired behaviors of the students, $z=2.807, p<.001$. The study aimed to change the undesired student behaviors into positive ones at secondary school students and it was concluded that "Psycho-Education Program for Increasing Positive Behavior" contributed to reducing undesired student behaviors and changing them with positive counterparts. In the light of the findings, it is recommended that school counselors working at secondary schools can use this program to deal with undesired student behaviors in future. 
GiRiş

Okul bir yaşantı alanı olarak, öğrencilerin pek çok davranışını gözleme fırsatı sağlamaktadır. Bu anlamda öğrencilerin okullarda sergiledikleri davranışları istenen ve istenmeyen davranış olarak sıralamak mümkündür. Eisenberg (1986) istenen davranışı; bireyin kendisi dışındakilere fayda sağlaması amacıyla yaptığı istekli davranışlar olarak tanımlamaktadır. Carr vd. (1999) ve Erbaş (2005) ise olumlu davranışı toplum, aile ve iş ortamında bireyi başarıya götüren ve sosyal doyumunu arttıran becerilerin bütünü olarak tanımlamışlardır. İstenen davranış, bireyin yaşamının her aşamasında ön plana çıkarken ergenlik döneminde de büyük bir önem kazanmaktadır. Ergenlik döneminde, ergenin ortaya koyduğu her olumlu davranışın bireyin hem gelişimine hem olumsuz durumlarla baş edebilmesine hem de hayatın her aşamasında daha uyumlu birey olmasına katkı sağladığı gibi ergenlerin daha iyi akran ilişkileri kurmasına da yardımcı olur (Caprara, Kanacri, Zuffiano, Gerbino ve Pastorelli, 2015). Bu anlamda Türkiye'de MEB'in 5. ve 6. sınıf ders kitaplarında öğrencilere açık veya örtük bazı olumlu davranışlar kazandırılmaya çalışılmıştır. Bunlar; başkalarını düşünme, cesaretli olma, çalışkan olma, dayanışma, disiplinli olma, eleştirel düşünme, empati kurma, fedakâr olma, hatalarının farkına varma/öz eleştiri yapma, kararlı/azimli olma, kitap okuma, meraklı olma, misafirperver olma, nazik olma, özgüven sahibi olma, sabırlı olma, saygılı olma, sorumluluk sahibi olma, sosyal olma, takdir etme, tedbirli olma, vatanını milletini sevme, yalan söylememe/dürüst olma, yaratıcı düşünme, yardımsever olma olarak sıralanabilir (Sevici, 2015).

Coie ve Dodge (1998) istenmeyen davranışı; bireyin kendisi dışındakilere isteyerek veya istemeyerek zarar vermesine neden olan davranış biçimi olarak tanımlamaktır. Pala (2005) ise istenmeyen davranışı, ortama ya da duruma göre uygunsuz yapılan hareketler olarak ifade etmiştir. Olaya eğitim açısından bakıldığında ise istenmeyen davranış, okuldaki eğitsel her türlü etkinliğin engellenmesine neden olan davranışların tümü (Yüksel, 2005) ya da dersin akışını bozan, kazanımlara ulaşmayı önleyen tüm davranışlar (Ilgar, 2005) olarak tanımlanmaktadır.

Bu tanımlardan hareketle sınıfta, okulda veya sosyal çevrede meydana gelen istenmeyen öğrenci davranışlarının eğitimdeki rolünün araştırılması düşünülmektedir. İstenmeyen öğrenci davranışları, sınıf içerisinde öğretmen ve öğrencilerin öğrenme sürecini olumsuz yönde etkilemektedir. Bununla beraber sınıf içerisinde öğrenciler arasında huzursuzluk yaşanmasına, öğretmenin daha gergin ve sinirli olmasına, sınıfın duygusal olarak negatif yönde etkilenmesine neden olur (Erdoğan, 2002). Öztürk (2002) okullarda öğrenciler tarafından sergilenen ancak eğitimciler tarafından istenmeyen davranışları üç başlık altında: fiziki ortama karşı, öğretmenlere karşı ve öğrencilere karşı yapılan davranışlar olarak sınıflandırmıştır. Baloğlu (2001) ise bu davranışları şu şekilde yapılandırmıştır: (a) Öğrencilerin fiziki ortama zarar vermesi; okuldaki materyallerin amaç dışı kullanımı ve bunlara zarar verme, kendi ders araç gereçlerine zarar verme, kendisine ait olmayan eşyaların izinsiz kullanımı; (b) Öğrencilerin eğitimciye karşı yaptığı istenmeyen davranışlar; öğretmene saygısızca davranma ve öğretmene karşı ders esnasında direnç gösterme, sınıfta söz hakkı istemeden konuşma, dersin yapılmasını engelleme ve ders esnasında gizli şekilde konuşma; (c) Öğrencinin kendisine ve diğer arkadaşlarına karşı istenmeyen davranışlar sergilemesi; arkadaşlarının dikkatini dağıtma, ders esnasında gizli şekilde konuşma, temizlik ve görgü kuralları dışında hareket etme, küfürlü ve kaba iletişim kurma, diğer kişileri rahatsız etme, işini özensiz ve dikkatsizce yapma, dersi dinlememe, ders esnasında ders dışı şeylerle ilgilenme, diğer kişilerin ders dinlemesi ve ders çalışmasını engelleme, sınavlarda kopya çekme ve okula devamsızıı.

Okullarda istenmeyen davranış sergileyen öğrencilerle yapılan araştırmalar incelendiğinde, öğrencilerin yeterince eğitim ve öğretim alamadıklarından dolayı başarısız olma endişesi taşıdıkları ve bu başarısızlığı örtmek için ise istenmeyen davranış gösterme eğilimi sergiledikleri gözlemlenmiştir (Chandler ve Dahlquist, 2002). Her ne kadar öğrenciler istenmeyen davranışlar sergilese de öğretmenlerin istenmeyen bu davranışlara karşı kullandıkları bir takım stratejiler vardır. Bunlar; görmezden gelme, göz teması kurma, öğrencinin yakınına gitme, öğrenciyi uyarma, azarlama, yer değiştirme, mizahı kullanma, haklarını kısıtlama, anlaşma yapma, veliyle iletişime geçme ve fiziksel olmayan ceza vermedir (Başar, 2001). İstenmeyen davranışlar gösteren çocuklarda bu davranışlara dikkat çekmek için ergenliğe girmeden bu davranışlar yerine olumlu davranışların kazandırılması gerekliliği ve erken müdahalenin önemi vurgulanmıştır (Beard ve Sugai, 2004). Bu yüzden öğrencileri etkileyen istenmeyen bu davranışların yerine olumlu davranışlar kazandırılmaya çalışılmalıdır.

İstenmeyen davranışları önlemek ve düzeltmek için öğretmenlerin başvurduğu bir diğer önemli yöntem ise kuralları sınıfta ve okulda işlevsel hale getirmektir. Kurallar henüz problem ortaya çıkmadan belirlenmiş kararlardır. Bu kurallar sayesinde öğrenci istenmeyen davranışları tanır, bu davranışları yaparsa bedelinin ne olacağını bilir ve buna göre davranır (Başar, 2001). Demiroğlu (2001) sınıf kurallarının öğrencilerle birlikte belirlenmesinin öğrencilerin kurallara uymasını kolaylaştırdığını tespit etmiştir. Aynı çalışmada öğretmenlerin derse hazırlıklı gelmesi, dersin planlı ve programlı bir şekilde işlenmesi, öğrencilerin sorunlarını öğretmenlerin sabır ve anlayışla dinlemesi ve karşılaması, ben dilini kullanması, yaşanan bir problem durumunda beden dilini kullanarak duygularını ifade etmesi, öğrencileri ders içi etkinliklere dâhil etmesi, öğrencilerin düşüncelerine önem vermesi gibi davranışların sınıftaki istenmeyen davranışları azaltmada önemli bir etkisinin olduğu belirtilmiştir.

Ülkemizde istenmeyen öğrenci davranışları ile ilgili yapılan bir araştırmada, Gündoğdu (2013) sınıfta veya okulda istenmeyen öğrenci davranışlarının nedenlerini ailevi, ekonomik, öğretmenden ve öğrenciden kaynaklı nedenler ile diğer nedenler olarak sınıflamıştır. Ayrıca çeşitli araştırmalarda öğretmenlere öğrencilerde gözlemledikleri istenmeyen davranışlar sorulmuş ve öğretmenlerin pek çok farklı noktayı vurguladığı görülmüştür: öğretmene saygısızlık, okuldan kaçma, okul ya da sınıf disiplinini bozma, kopya çekme (Eripek,1980); sigara içme, dersten kaçma, kahvehanede oyun oynama (Türkeç, 1986; Uysal, 1991); sağa sola bakma, ders dışında başka bir şeyle uğraşma, verilen görevleri yapmama, sınıfta bir şeyler yeme, hırsızlık, arkadaşlarına kaba ve küfürlü konuşma, yalan söyleme, saldırganlık (Aksoy, 2014; Danaoğlu, 2009; Kocabey, 2008; Sadık, 2000; Sayın, 2001); gereksiz soru sormak, sürekli tuvalet izni istemek, arkadaşlarının canını acıtmak, ev ödevlerini yapmamak, sınıf içi görevlerini

| Kastamonu Eğitim Dergisi, 2020, Vol. 28, No. 6| 
yerine getirmemek, ders için gerekli materyalleri getirmemek, dinliyor gibi görünmek ama dinlememek, konu ya da cevabı bilmesine karsın derse katılmamak, öğretmenine küsmek (Çetin, 2002; Öztürk, 2001); sınıfa gürültüyle girme ve çıkma, diğer öğrencilerin sınıfa girişinde ve çıkışında dengelerini bozacak davranışlarda bulunma, diğer öğrencileri kızdırma (Keskin, 2002); hep kendisine söz verilmesini isteme (Alkan, 2002); çalışmaya dikkatini toplayamamak, bir yerde uzun süreli oturamamak ve derste sıraların arasında dolaşmak (Yüksel, 2005); sürekli ön planda olmayı isteme (Neyişçi-Karakaş, 2005); uyumsuzluk, uygunsuz davranışlarla diğer öğrencilere kötü örnek olma (Durulmuş, 2018); arkadaşlarının öğrenmesini engelleme, güvenliğini tehlikeye atacak şekilde davranma, okulun ya da kişilerin araç ve gereçlerine zarar verme, sosyalleşme anlamında engelleyici olma (Durulmuş, 2018; Öz, 2018) başlıca ön plana çıkan istenmeyen davranışlardır.

Uluslararası alan yazında istenmeyen öğrenci davranışlarına yönelik yapılan araştırmalarda ise derse hazırlıksız gelme (Weishew ve Peng, 1993); sınıfta sigara içme, arkadaşına yönelik özel şiddet uygulama, okul araç ve gerecini çalma, okulun kurallarını çiğneme (Romi ve Fruend, 1999); sınıfta izinsiz konuşma (Türnüklü, 2000); başkalarının kişisel eşyalarına dokunma, zamansız ve rahatsız edecek şekilde konuşma, itaatsizlik (Walker, Cheney, Stage ve Blum, 2005); öfke nöbeti, kavga etme, yalan söyleme, hırsızlık, saygısızlık, yerinde duramama, dikkatini toplayamama, dikkat eksikliği ve düşünmeden davranma (Hayes, 2007); ödevlerini düzenli olarak yapmama, aklına geldiği gibi davranma, yeni durumlara uyum sağlamada güçlük yasama (Baker, Clark, Maier ve Viger, 2008); madde bağımlıı̆̆ı, silah kullanımı, zorbalık, okuldan kaçma ve saldırgan davranışlar sergileme (Crone, Hawken ve Horner, 2010); fiziksel ve ilişkisel saldırganlıkta bulunma (Low, Polanin ve Espelage, 2013); izinsiz konuşma, ders esnasında başka bir arkadaşına not yazıp gönderme, şeker yeme, yere çöp atma (Emmer ve Evertson, 2013) gibi davranışların ön plana çıktığı görülmektedir.

Alan yazına bakıldığında istenmeyen öğrenci davranışlarını olumlu davranışlarla değiştirmek veya ortadan kaldırmak için öğretmenlerin; sorunu anlama, görmezden gelme, göz teması kurma, sorumluluk verme, ceza verme, kızma, birebir konuşma, söz hakkı verme, empati kurma, görev verme, sözlü uyarı, yer değişikliği, aile ile görüşme, rehberlik servisine yönlendirme, olumlu pekiştireç verme, rencide etmeme, sorumluluk verme, hoşgörülü olma, probleme odaklanma, öğüt verme ve sert davranma, öğrenciyle konuşma, davranışı açıklama, kuralları hatırlatma, ödül-ceza, çözümü kendilerine bırakma, veli ile iletişim kurma, yardım etme, bireysel farkları dikkate alma, sorumluluk verme, yol gösterme, değer verme ve hoşgörülü olma (Gündoğdu, 2013; Sakallığlu, 2014); aileyi bilinçlendirme, aile ile işbirliği yapma, rehberlik ve danışmanlık alanında işbirliği yapma, aileyi eğitme, rehberlik servisiyle işbirliği yapma, televizyondaki programlara düzenlemeler getirme, okulda değerler eğitimi verme, veli toplantıları yapma (Aksoy, 2014); dersi eğlenceli hale getirme, olumlu davranış gösteren öğrenciyi örnek gösterme, öğrenciyi derse katmaya çalışma, öğrenciyi onore etme, öğrenciye hafifçe dokunma (Öz, 2015); tablet-akıllı tahta ile ders işleme, uyarma, öğrenciyi işbirliğine teşvik etme, somutlaştırma, görselleştirme, dikkati toplayacak etkinlikler yapma, öğretim yöntemini değiştirme, dersi günlük hayatla ilişkili hale getirme, oyun oynatma, yarışma yaptırma, basit sorular sorma, dersi tekrarlama, oturma düzenini değiştirme, dersin öneminden bahsetme, farklı kaynaklara başvurma gibi stratejiler uyguladıkları görülmektedir (Öz, 2018). Ancak uygulanan bu stratejiler istenmeyen öğrenci davranışlarını önleme veya ortadan kaldırmaya yönelik pozitif sonuçlar verse de araştırmaların sayısı yeterli düzeyde değildir. Bu nedenle uygulamalı eğitimlerin artması, psiko-eğitim grup etkinliklerinin çoğaltılması alan yazına önemli bir zenginlik katacaktır.

Alan yazın ışığında okulda ve sınıfta istenmeyen öğrenci davranışlarını tespit etmek için birçok araştırma yapıldığı görülmektedir. Ancak bu araştırmaların genellikle istenmeyen öğrenci davranışlarını belirlemeye odaklandığı, istenmeyen bu davranışların olumlu davranışlarla değiştirilmesine yönelik uygulamalı çalışmaların az olduğu göze çarpmaktadır. Ayrıca Gaziantep İ Milli Eğitim Müdürlüğünün 2020-2021 eğitim-öğretim yılı yerel rehberlik programı hedeflerinden biri de olumlu davranış geliştirme olduğu saptanmıştır. Dolayısıyla, istenmeyen davranışları azaltmaya yönelik deneysel çalışmaların yapılması ve alan yazının zenginleştirilmesi gerekli ve önemlidir. Bu noktadan hareketle, bu araştırmanın genel amacı, düşük sosyoekonomik düzeye sahip iki ortaokulda istenmeyen öğrenci davranışları sergileyen 5. ve 6. sınıf öğrencileri için hazırlanan "Olumlu Davranış Kazandırmaya Yönelik Psiko-Eğitim Programı”nın etkililiğini incelemektir. Bu genel amaç çerçevesinde şu soruya yanıt aranmıştır: Olumlu davranış kazandırmaya yönelik hazırlanan psiko-eğitim programı istenmeyen davranış sergileyen öğrencilerin "olumlu davranış" gösterme düzeylerini anlamlı ölçüde arttırmış mıdır?

\section{YÖNTEM}

Araştırmanın bu bölümünde bu araştırmanın desenine, araştırmaya katılan çalışma grubuna, veri toplama aracına, verilerin toplanmasına, uygulama sürecine ve veri analizine dair bilgiler verilmiştir.

\section{Araştırmanın Deseni}

Ortaokul öğrencilerinde olumlu davranış geliştirmeyi amaçlayan bu çalışma yarı deneysel bir çalışma şeklinde planlanmıştır. Deneysel araştırmalar; araştırmacı tarafından oluşturulan farkların bağımlı değişken üzerindeki etkisini test eden araştırmalardır. Burada asıl amaç, değişkenler arasında oluşturulan neden sonuç ilişkisini test etmektir (Büyüköztürk, Kılıç Çakmak, Akgün, Karadeniz ve Demirel, 2012). Araştırmacı bu amacını gerçekleştirmek için bağımsız değişkenin düzeyleri olan işlem gruplarına seçkisiz atama yapmak, bağımsız değişkeni manipüle etmek, dışsal değişkenleri kontrol altına almak durumundadır (Borg ve Gall, 1989; akt. Büyüköztürk vd., 2012). Deneysel araştırmalar; tek denekli desenler ve çok denekli desenler olmak üzere ikiye ayrılırken tek denekli desenler ise bir ya da bazı durumlarda birden çok denekle çalışılan ve değişimlerin grafiklerle izlendiği bir 
zaman serisi çalışması olarak tanımlanmaktadır (Büyüköztürk vd., 2012). Bu çalışmanın deseni, araştırmaya katılan deneklerin seçilmesi ve atanması bakımından tek denekli $A B$ deneysel desenidir. Tek denekli AB deneysel desenler; araştırmaya başlamadan önce bağımlı değişkenin durumu tespit edildikten sonra (ön-test) bağımsız değişkenin bağımlı değişken üzerindeki etkisinin ölçülmesi için bağımsız değişkenin uygulandığı (son-test) deneysel desenlerdir (Büyüköztürk vd., 2012).

\section{Çalışma Grubu}

Araştırmanın çalışma grubunu, 2018-2019 eğitim-öğretim yılında, Adıyaman ili Sincik ilçesi ile Gaziantep ili Merkez ilçesindeki düşük sosyo-ekonomik düzeye sahip iki devlet ortaokulunda öğrenim gören öğrenciler oluşturmaktadır. Çalışmaya Adıyaman ilindeki okuldan 10, Gaziantep ilindeki okuldan 10 olmak üzere toplamda 20 öğrenci katılmıştır. Katılımcıların 9'u kız, 11'i erkek öğrencidir ve tamamı 5. veya 6. sınıf öğrencisidir. Araştırmaya katılan deney gruplarına ilişkin tanımlayıcı istatistikler Tablo 1 'de verilmiştir.

Tablo 1. Deney grubuna ilişkin tanımlayıcı istatistikler

\begin{tabular}{|c|c|c|c|c|}
\hline & & Ortaokul-I (Adıyaman) & Ortaokul-II (Gaziantep) & $N$ \\
\hline \multirow[t]{2}{*}{ Sinıf } & 5. Sinif & 1 & 3 & 4 \\
\hline & 6. Sinıf & 9 & 7 & 16 \\
\hline \multirow[t]{2}{*}{ Cinsiyet } & $\mathrm{K} ı \mathrm{z}$ & 4 & 5 & 9 \\
\hline & Erkek & 6 & 5 & 11 \\
\hline Toplam & & & & 20 \\
\hline
\end{tabular}

\section{Veri Toplama Aracı}

\section{İstenmeyen Öğrenci Davranışları Ölşeği}

“i̇stenmeyen Öğrenci Davranışları Ölçeği”; istenmeyen öğrenci davranışlarını belirlemek amacıyla Alkaş (2010) tarafından geliştirilmiş olan 4'lü Likert tipi (4: her zaman yaparım - 1: hiç yapmam) 29 maddeden oluşan bir ölçektir. Ölçek “Kurallara Uymama”, "Kişilere Zarar Verme", "Aşağılama” ve "Kendine Zarar Verme” olmak üzere dört alt faktörden oluşmaktadır. Ölçeğin ilk 8 maddesi olumlu davranışları ölçerken, sonraki 21 maddesi olumsuz davranışları ölçmektedir. Ölçekten alınabilecek en düşük puan 29, en yüksek puan ise 116 'dır. Ölçeğin uygulama süresi 25 dakikadır. Ölçekte katılımcıların alacağı düşük puanlar istenmeyen öğrenci davranışlarını gösterirken yüksek puanlar ise istendik öğrenci davranışlarını göstermektedir. Ölçek geliştirme çalışması 573 ilköğretim öğrencisinin katılımıyla gerçekleştirilmiştir. Ölçeğin iç tutarlılık katsayısı 83’tür. Bununla beraber ölçeğin KMO değeri 83, ölçek maddelerinin toplam açıkladığı varyans ise 44.7'dir (Alkaş, 2010). Ölçeği kullanmak için ölçeği geliştiren araştırmacıdan gerekli izinler e-posta yoluyla alınmıştır.

\section{Verilerin Toplanması}

Gerekli resmi izinlerin alınmasının ardından, uygulamaya başlamadan önce psiko-eğitim programını uygulayacak öğrencileri belirlemek amacıyla Adıyaman ilindeki bir köy ortaokulu ( $N=70$ ) ile Gaziantep ilindeki bir köy ortaokulunda bulunan ( $N=80$ ) ve 5 . ve 6. sınıflardan oluşan toplam 150 öğrenciye "İstenmeyen Öğrenci Davranışları Ölçeği” uygulanarak (ön-test) her iki okulda da en düşük puanı alan 10 öğrenci tespit edilerek seçilmiştir. Araştırmaya katılım için öğrencilerin kendileri ve velileri bilgilendirilmiş ve gönüllü olanların araştırmaya katılımı sağlanmıştır. Araştırmada, yapılandırılmış uygulamalar altı hafta boyunca iki okulda da haftanın aynı günü yapılmış ve bir saat sürmüştür. Olumlu davranış geliştirmeye yönelik uygulanan grup rehberliği programının sonunda "istenmeyen Öğrenci Davranışları Ölçeği”" tekrar uygulanmıştır (son-test).

\section{Uygulama Süreci}

Bu çalışmada kullanılan psiko-eğitim programının hazırlanmasında bir dizi aşama takip edilmiştir. Yüksek lisans dersi olan “Okul Danışmanlığında Uygulama” kapsamında bir öğretim üyesi ve üç lisansüstü öğrenci bir araya gelerek bir günlük bir çalıştay yapmıştır. Bu çalıştayın sonunda düşük sosyo-ekonomik düzeye sahip öğrencilerin çoğunlukta olduğu ortaokullarda çalışan 10 okul psikolojik danışmanı ile görüşülmüş, okullarında öğrenci davranışları ile ilgili en çok ihtiyaç duydukları konular sorulmuştur. Okul psikolojik danışmanları, öğrencilerde en çok karşılaştıkları problem alanının istenmeyen öğrenci davranışları olduğunu iletmiş ve bu konuda programa ihtiyaçlarının olduğunu bildirmişlerdir. Bu aşamadan sonra alan yazın taraması yapılmıştır. Bu noktada, istenmeyen öğrenci davranışlarını tespit etmek için birçok araştırmanın yapıldığı ancak istenmeyen öğrenci davranışlarını olumlu öğrenci davranışlarına çevirmeye yönelik uygulamalı çalışmaların yetersiz olduğu görülmüştür. Çalışmanın üçüncü aşamasında çalışmayı yapacak olan araştırmacılar tekrar bir araya gelerek ikinci bir çalıştay yapmışlardır. Bu çalıştayda okullarda okul psikolojik danışmanları ve öğrencilerin ihtiyacı olan "Olumlu Davranış Kazandırma" programının hazırlanmasına karar verilmiştir. Çalışmanın dördüncü aşamasında araştırmacılar çalışmada kullanılacak ölçme aracını belirlemiş ve 6 oturumluk 
psiko-eğitim programının formatını oluşturmuşlardır. Bunun yanı sıra, çalışmanın yapılacağı okullara karar verilerek gerekli izinler alınmıştır. Çalışmada kullanılacak olan ölçek öğrencilere uygulanarak (ön-test) en düşük puan alan 20 öğrenci belirlenmiştir. Çalışmanın beşinci aşamasında “Olumlu Davranış Kazandırmaya Yönelik Psiko-Eğitim Programı”na son hali verilmiştir. Altıncı aşamada öğretim üyesi danışmanlığında hazırlanan program belirlenen okullarda 6 hafta süresince lisansüstü öğrencileri tarafından uygulanmıştır. Çalışmanın yedinci aşamasında ise çalışmanın son oturumu yapıldıktan sonra katılımcı öğrencilere çalışmada kullanılan ölçek tekrar (son-test) uygulanmış ve analizler yorumlanmıştır.

Psiko-eğitim programı Adıyaman'da bir grup lideri tarafından, Gaziantep'te ise bir grup lideri ve bir eş lider (co-leader) tarafından uygulanmıştır. Eş lider ile yürütülen grupta roller ve görev dağılımları önceden yapılandırılmıştır. Psiko-eğitim programı her hafta okullarda uygulanmadan önce programda gerekli olan materyaller hazırlanmış ve okullara götürülmüştür. Araştırmada katılımcılara uygulanan “Olumlu Davranış Kazandırmaya Yönelik Psiko-Eğitim Programı” oturumlarının içeriği, yeterlik alanı ve kazanımları Tablo 2'de verilmiştir.

Tablo 2. Olumlu davranış kazandırmaya yönelik psiko-eğitim programının aşamaları

\begin{tabular}{|c|c|c|c|}
\hline \multirow[t]{3}{*}{1.} & Oturum & Etkinlik adı & Olumlu ilişki kurma yolları \\
\hline & & Yeterlik alanı & Kişiler arası olumlu ilişki kurma \\
\hline & & Kazanım & Kişiler arası olumlu ilişkiler kurma yollarını fark eder \\
\hline \multirow[t]{3}{*}{2.} & Oturum & Etkinlik adı & Hayır demek istiyorum \\
\hline & & Yeterlik alanı & İstemediği bir durumla karşılaşınca bunu dile getirebilme \\
\hline & & Kazanım & Onaylamadığında hayır diyebilir \\
\hline \multirow[t]{3}{*}{3.} & Oturum & Etkinlik adı & Duygularımızı tanıyalım \\
\hline & & Yeterlik alanı & Duyguları hakkında bilgi sahibi olma \\
\hline & & Kazanım & Olaylarla duygular arasındaki ilişkiyi kavrayabilir \\
\hline \multirow[t]{3}{*}{4.} & Oturum & Etkinlik adı & A - B - C - D tekniğini öğrenme \\
\hline & & Yeterlik alanı & Düşüncelerini fark etme ve önemini kavrama \\
\hline & & Kazanım & Düşüncelerle duygular, davranışlar arasındaki ilişkiyi kavrayabilir \\
\hline \multirow[t]{3}{*}{5.} & Oturum & Etkinlik adı & Saygılı olma \\
\hline & & Yeterlik alanı & Çevresindeki kişilere saygılı olma \\
\hline & & Kazanım & Saygılı olmanın önemi ve kimlere saygı duyulması gerektiğini kavrayabilir \\
\hline \multirow[t]{3}{*}{6.} & Oturum & Etkinlik adı & Grup sürecinin değerlendirilmesi \\
\hline & & Yeterlik alanı & Grup sürecindeki kazanımlarını ifade eder \\
\hline & & Kazanım & Grup üyeleri grup oturumlarından ne kazandıklarını kavrayabilirler \\
\hline
\end{tabular}

\section{Verilerin Analizi}

Araştırma kapsamında deney grubunun demografik özelliklerine ilişkin tanımlayıcı istatistiklere yer verilmiştir. Bunun yanı sıra, veri analizi deney grubundaki denek sayısı parametrik testler için yetersiz olduğundan, parametrik olmayan Wilcoxon sıralı işaretler testi kullanılarak yapılmıştır. Wilcoxon işaretli sıralar testi; ilişkili iki örneklem puanlarının dağılımlarının birbirinden manidar bir şekilde farklılık gösterip göstermediğini test etmek için kullanılır (Balcı, 2010).

\section{BULGULAR}

Bu bölümde araştırmaya katılan deney gruplarına ait ön-test-son-test uygulamasının betimsel istatistik sonuçları ve ön-test ve son-test sonrası istenmeyen öğrenci davranışları testi puanlarının Wilcoxon işaretli sıralar testi sonuçları verilmiştir. Ortaokul-ı öğrencilerinde İstenmeyen Öğrenci Davranışları Ölçeği'ne ait betimsel istatistik sonuçları Tablo 3'te verilmiştir. 
Tablo 3. Ortaokul-ı iöDÖ Betimsel istatistik sonuçları

\begin{tabular}{|c|c|c|c|c|c|}
\hline Ölçek & $N$ & Ortalama & SS & Minimum & Maximum \\
\hline Ön-test & 10 & 75.80 & 6.90 & 61.00 & 86.00 \\
\hline Son-test & 10 & 102.80 & 10.39 & 82.00 & 115.00 \\
\hline
\end{tabular}

Tablo 3'e bakıldığında katılımcılardan ön-testte elde edilen minimum puan 61.00 iken maksimum puan 86.00; son-testteki minimum puanları 82.00 iken maksimum puanları 115'tir. Ayrıca ön-test ortalama puanları $\bar{x}=75.80$ iken son-test ortalama puanları $\bar{x}=102.80$ 'e çıkmıştır. Ön-test ile son-test ortalama puanı arasında $\bar{x}=27.00$ puanlık bir artış olduğu tespit edilmiştir. Öntest ile son-test ortalama puanı arasındaki bu farkın anlamlı olup olmadığını anlamak için Wilcoxon işaretli sıralar testi uygulanmıştır. Ortaokul-I öğrencilerinde istenmeyen öğrenci davranışlarına yönelik yapılan zayıf deneysel çalışma sonucunda elde edilen Wilcoxon işaretli sıralar testi sonuçları Tablo 4 'te verilmiştir.

Tablo 4. Ortaokul-ı ön-test ve son-test sonrası istenmeyen öğrenci davranışları testi puanlarının Wilcoxon işaretli sıralar testi sonuçları

\begin{tabular}{|c|c|c|c|c|c|}
\hline Son-test - ön-test & $N$ & Sıra ortalaması & Sıra toplamı & $z$ & $p$ \\
\hline Negatif sıra & 0 & 0.00 & 0.00 & 2.807 & $.005^{*}$ \\
\hline Pozitif sıra & 10 & 5.50 & 55.00 & & \\
\hline Toplam & 10 & - & - & & \\
\hline
\end{tabular}

$* p<.05$

Tablo 4 incelendiğinde, katılımcıların “istenmeyen Öğrenci Davranışları Ölçeği”nde uygulama öncesi ve uygulama sonrası puanları arasında anlamlı bir fark olduğu tespit edilmiştir, $z=2.807, p<.05$. Fark puanlarının sıra ortalaması ve toplamları dikkate alındığında, gözlenen bu farkın pozitif sıralar, yani son-test puanı lehinde olduğu görülmektedir. Ortaokul-Il öğrencilerinde İstenmeyen Öğrenci Davranışları Ölçeği'nin betimsel istatistiksel sonuçları ise Tablo 5'te verilmiştir.

Tablo 5. Ortaokul-II iöDÖ Betimsel istatistik sonuçları

\begin{tabular}{|c|c|c|c|c|c|}
\hline Ölçek & $N$ & Ortalama & SS & Minimum & Maximum \\
\hline Ön-test & 10 & 99.60 & 5.27 & 90.00 & 104.00 \\
\hline Son-test & 10 & 108.40 & 4.69 & 100.00 & 113.00 \\
\hline
\end{tabular}

Tablo 5'e bakıldığında, katılımcılarda ön-testte elde edilen minimum puan 90.00 iken maksimum puan 104.00; son-testeki minimum puanları 100.00 iken maksimum puanları 113.00'tir. Bunun yanı sıra ön-test ortalama puanları $\bar{x}=99.60$ iken son-test ortalama puanları $\bar{x}=108.40$ 'a çıkmıştır. Ön-test ile son-test ortalama puanı arasında $\bar{x}=8.80$ puanlık bir artış olduğu tespit edilmiştir. Ön-test ile son-test ortalama puanı arasındaki bu farkın anlamlı olup olmadığını anlamak için Wilcoxon işaretli sıralar testi uygulanmıştır. Ortaokul-Il öğrencilerinde istenmeyen öğrenci davranışlarına yönelik yapılan zayıf deneysel çalışma sonucunda elde edilen Wilcoxon işaretli sıralar testi sonuçları Tablo 5 'te verilmiştir. 
Tablo 6. Ortaokul-ıl ön-test ve son-test sonrası istenmeyen öğrenci davranışları testi puanlarının Wilcoxon işaretli sıralar testi sonuçları

\begin{tabular}{|c|c|c|c|c|c|}
\hline Son-test - ön-test & $N$ & Sıra ortalaması & Sıra toplamı & $z$ & $p$ \\
\hline Negatif sıra & 0 & 0.00 & 0.00 & 2.807 & $.005^{*}$ \\
\hline Pozitif sıra & 10 & 5.50 & 55.00 & & \\
\hline
\end{tabular}

Toplam

$* p<.05$

Tablo 6 incelendiğinde, katılımcıların “istenemeyen Öğrenci Davranışları Ölçeği”nde uygulama öncesi ve uygulama sonrası puanları arasında anlamlı bir fark olduğu tespit edilmiştir, $z=2.807, p<.05$. Fark puanlarının sıra ortalaması ve toplamları dikkate alındığında, gözlenen bu farkın pozitif sıralar yani son-test puanı lehinde olduğu görülmektedir. Sonuç olarak, elde edilen tüm bulgular, olumlu davranış kazandırmaya yönelik uygulanan psiko-eğitim programının iki grubun son-test puanlarında anlamlı bir artışa sebep olduğunu ve programın etkili olduğunu göstermiştir.

\section{TARTIŞMA}

Bu çalışmanın amacı, okullarda istenmeyen öğrenci davranışları sergileyen 5. ve 6. sınıf öğrencileri için hazırlanan “Olumlu Davranış Kazandırmaya Yönelik Psiko-Eğitim Programı”nın etkililiğini incelemektir. Bu amaç doğrultusunda iki farklı ortaokulda istenmeyen öğrenci davranışları sergileyen öğrencilere "İstenmeyen Öğrenci Davranışları Ölçeği (iÖDÖ)" uygulanarak (ön-test) testte en düşük puanı alan öğrenciler tespit edilmiştir. “Olumlu Davranış Kazandırmaya Yönelik Psiko-Eğitim Programı”nı uygulamak için gerekli izinler alındıktan sonra hazırlanan program, her iki okulda da haftada bir saat olmak üzere altı hafta boyunca uygulanmıştır. Bu uygulamanın sonunda aynı öğrencilere iöDÖ tekrar uygulanarak (son-test) “Olumlu Davranış Kazandırmaya Yönelik Psiko-Eğitim Programı"nın istenmeyen davranış sergileyen öğrencilerin davranışları üzerinde ne ölçüde etkili olduğu araştırılmıştır. Bu doğrultuda ele alınan hedef ve davranışlara yönelik bulgular ve uygulama esnasında katılımcıların verdikleri geri bildirimler aşağıda tartışılıp yorumlanmıştır.

Araştırmada “Olumlu Davranış Kazandırmaya Yönelik Psiko-Eğitim Programı”na katılan öğrencilerin ön-test ve son-test puanları arasında anlamlı bir fark olduğu ve olumlu davranış sergileme puanlarının yükseldiği görülmüştür. Dolayısıyla psikoeğitim programının öğrencilerin olumlu davranış sergilemelerine katkı sağladığı sonucuna ulaşılmıştır. Elde edilen veriler, katılımcıların program sonrasında istenmeyen davranışları azalttığını ve daha olumlu davranışlar sergilemeye başladıklarını göstermiştir. Bu bulgulardan hareketle, "Olumlu Davranış Kazandırmaya Yönelik Psiko-Eğitim Programı"nın araştırmaya katılan her iki okulun 5. ve 6. sınıflarında okuyan öğrencilerin istenmeyen öğrenci davranışlarını azaltmada etkili bir program olduğu sonucuna ulaşılmıştır.

İlgili alan yazında, deneysel çalışmalarda uygulanan programlar sonrasında, öğrencilerin istenmeyen öğrenci davranışlarını azaltıp istenmeyen davranışlar yerine olumlu davranışlar geliştirdikleri belirtilmiştir (Arslan, 2007; Bilge, Bilge ve Ertekin, 2016; Bulut Serin ve Genç, 2011; Doğru ve Peker, 2004; Gündoğdu ve Izgar, 2010; Hastunç, 2018; ỉkiz ve Gül, 2017; Öz, 2008; Sadri Damırchı, 2014; Şahin, 2004; Uşaklı, 2006). Benzer şekilde, Doğru ve Peker (2004) çalışmalarında özsaygı geliştirme programının uygulanmasından sonra deney grubundaki katılımcıların kontrol grubundaki katılımcılara göre kendini ifade etme, karşılıklı kabul, duygularını tanıma ve ifade etme, olumlu benlik algısı ve kendine değer verme, amaçlarını belirleme ve sorumluluk alma, girişken olma gibi olumlu davranışlar sergilediklerini belirtmiştir. Şahin (2004) araştırmasında, öfke denetimi eğitiminden sonra deney grubundaki öğrencilerin kontrol grubundaki öğrencilere göre öfke puanlarında anlamlı bir düşüş olduğunu saptamıştır. Uşaklı (2006) çalışmasında drama temelli grup rehberliği programının uygulanmasından sonra deney grubundaki öğrencilerin kontrol ve plasebo grubundaki öğrencilere göre arkadaşlık ilişkilerinde, atılganlık düzeylerinde ve benlik saygılarında anlamlı bir artışın olduğunu saptamıştır. Benzer şekilde, Arslan (2007) ilköğretim okullarında istenmeyen davranışlara yönelik yaptığı araştırmada, öğretmenlerin sınıflarda uyguladıkları ödül ve ceza uygulamasının istenmeyen öğrenci davranışlarını öğrencilerin terk etmelerinde etkili bir yöntem olduğunu tespit etmiştir. Ayrıca, Öz (2008) çalışmasında öfke yönetimi eğitiminden sonra deney grubundaki katılımcıların kontrol ve plasebo grubundaki öğrencilere göre içe ve dışa dönük öfkelerini kontrol altına alma noktasında etkili olduğunu ve bununda iletişim becerilerine doğrudan katkısının olduğunu ifade etmiştir. Gündoğdu ve Izgar (2010) ise çalışmalarında yaratıcı drama temelli çatışma çözme programının uygulanmasından sonra deney grubundaki katılımcıların kontrol ve plasebo grubundaki öğrencilere göre saldırganlık puanlarında anlamlı düzeyde bir düşüş ve iletişim becerilerinde ise anlamlı düzeyde bir artışın olduğunu belirtmiştir.

Bulut Serin ve Genç (2011) çalışmalarında, öfke yönetimi programının katılımcıların öfke puanlarında anlamlı düzeyde bir düşüş oluşturduğu sonucuna ulaşmıştır. Sadri Damırchı (2014) çalışmasında, barış eğitimi programının deney grubundaki katılımcıların çatışma çözme ve iletişim becerilerinde kontrol grubu katılımcılarına göre anlamlı düzeyde bir artış olduğunu belirtmiştir. Benzer şekilde, iletişim becerileri psiko-eğitim programının uygulanmasından sonra deney grubundaki katılımcıların 
sosyal fobi düzeylerinde kontrol grubundaki katılımcılara göre anlamlı bir düşüş olduğunu belirtilmiştir (Bilge, Bilge ve Ertekin, 2016). Hastunç (2018) ise çalışmasında, deney grubundaki öğrencilerin kontrol grubuna göre uygulama sonunda tükenmişlik ve yabancılaşma puanlarının anlamlı bir şekilde düştüğünü ifade etmiştir. Tüm bu bulgular, istenmeyen öğrenci davranışlarını olumlu davranışla değiştirmek için bu araştırma kapsamında hazırlanan “Olumlu Davranış Kazandırmaya Yönelik Psiko-Eğitim Programı"nın bulgularını destekler niteliktedir. Dolayısıyla, etkililiği test edilen bu programın istenmeyen öğrenci davranışlarının azalmasına veya ortadan kalkmasına katkı sunacağı düşünülmektedir.

\section{ARAŞTIRMANIN SINIRLILIKLARI}

Uygulanan psiko-eğitim programı etkili sonuç vermesine rağmen bu araştırma bazı sınırlılıklara sahiptir. Araştırmada, tek denekli zayıf deneysel desen kullanılmıştır. Sonraki araştırmaların kontrol ve deney grubunun da içinde olduğu tam deneysel desen şeklinde tasarlanması önerilebilir. Ayrıca bu araştırma sadece iki ortaokulda yapılmıştır. Bu bakımdan araştırma, elde edilen bulguların bütün ortaokullara genellenememesi yönüyle sınırlıdır. Son olarak, araştırmada psiko-eğitim programının oldukça yapılandırılmış bir süreci takip etmesi sağlansa da, iki ayrı köy okulunda yürütülen bu çalışmada grupları farklı liderler yönetmiştir. Yani farklı grup liderlerinin kendi kişisel özelliklerini sürece dâhil etmiş olabileceği göz önünde bulundurularak sonuçlar yorumlanmalıdır.

\section{SONUÇ VE ÖNERILER}

Bulgulardan yola çıkılarak araştırmacıların gelecekte planlayacakları çalışmalarda yararlanabilecekleri bazı öneriler sıralanmıştır: Öncelikle, istenmeyen davranışları ortadan kaldırmak için farklı değişkenler de dikkate alınarak çeşitli programlar tasarlanabilir. Gelecekteki çalışmalarda katılımcıların yalnızca ölçekten elde edilen verilerle değil öğretmenler, akranlar ya da ailelerle yapılacak olan görüşmeler ışığında belirlenmesi önerilebilir. Bu doğrultuda, öğretmen ve velilerin de görüşlerinin alındığı karma çalışmalar tasarlanabilir. Ayrıca, programda öğretmen, akran ve aile desteğini de içerecek düzenlemeler yapılması faydalı olabilir. Alan yazında istenmeyen davranışlar karşısında bilimsel temeli olmayan yöntemler kullanan öğretmenlerin daha ciddi istenmeyen davranışların ortaya çıkmasına neden olduğu açıklanmıştır. Bu nedenle, istenmeyen davranış gösteren öğrencilerle çalışırken aynı zamanda öğretmenler ve velilerle öğrencilere nasıl davranılması gerektiğine yönelik çalışmalar yapılması faydalı olabilir. Ayrıca, gelecekte yapılacak çalışmalarda olumlu değişimin devamını takip etmek amacıyla izleme oturumu yapılmasının faydalı olacağı düşünülmektedir. Son olarak, bu çalışma istenmeyen davranış sergileyen öğrenciler ile yürütüldüğü için her oturumda kuralları hatırlatma ihtiyacı duyulmuştur. İstenmeyen davranış sergileyen öğrencilerle yapılacak daha sonraki çalışmalarda bu durum göz önünde bulundurularak düzenlemeler yapılması faydalı olabilir.

\section{KAYNAKÇA}

Aksoy, S. (2014). Öğrencilerde görülen istenmeyen davranışların nedenleri ve çözüm yolları ile ilgili öğretmen ve veli görüşleri. (Yayımlanmamış yüksek lisans tezi). Zirve Üniversitesi, Sosyal Bilimler Enstitüsü, Gaziantep.

Alkan, V. (2002). Ilköğretim 1. kademe öğrencilerinin sınıf-içi uygun olmayan davranışları gösterme sıklıkları ve bu davranışların öğretmen performansına etkisi. (Yayımlanmamış yüksek lisans tezi). Pamukkale Üniversitesi, Sosyal Bilimler Enstitüsü, Denizli.

Alkaş, B. (2010). Illköğretim öğrencileri arasındaki istenmeyen öğrenci davranışlarının incelenmesi. (Yayımlanmamış yüksek lisans tezi). Ankara Üniversitesi, Eğitim Bilimleri Enstitüsü, Ankara.

Arslan, H. (2007). Illköğretim okullarında istenmeyen davranışların düzeltilmesinde ödül ve cezanın öğrenci davranışları üzerindeki etkisi. (Yayımlanmamış yüksek lisans tezi). Yeditepe Üniversitesi, Sosyal Bilimler Enstitüsü, İstanbul.

Baker, J., Clark, T., Maier, K., \& Viger, S. (2008). The differential influence of instructional context on the academic engagement of students with behavior problems. Teaching and Teacher Education, 24, 1876-1883. https://doi.org/10.1016/j.tate.2008.02.019.

Balcı, A. (2010). Sosyal bilimlerde araştırma: Yöntem, teknik ve ilkeler (Gözden geçirilmiş ve genişletilmiş 8. Baskı). Ankara: Pegem Yayıncılık.

Baloğlu, N. (2001). Etkili sınıf yönetimi. Ankara: Baran Ofset.

Başar, H. (2001). Sınıf yönetimi (5. Baskı). Ankara: Pegem Yayıncılık.

Beard, K. Y., \& Sugai, G. (2004). First step to success: An early intervention for elementary children at risk for antisocial behavior. Behavioral Disorders, 29(4), 396-409. https://doi.org/10.1177\%2F019874290402900407.

Bilge, Y., Bilge, Y. ve Ertekin, G. (2016). Ergenlerde iletişim becerileri psiko-eğitim programının sosyal fobi üzerindeki etkisinin incelenmesi. Çekmece Izü Sosyal Bilimler Dergisi, 4(8-9), 199-214.

Bulut Serin, N. ve Genç, H. (2011). Öfke yönetimi eğitimi programının ergenlerin öfke denetimi becerilerine etkisi. Eğitim ve Bilim, 36(159), 236254.

Büyüköztürk, Ş., Kılıç Çakmak, E., Akgün, Ö. E., Karadeniz, ş. ve Demirel, F. (2012). Bilimsel araştırma yöntemleri (Geliştirilmiş 11. Baskı). Ankara: Pegem Yayıncılık.

Caprara, G. V., Kanacri, B. P. L., Zuffiano, A., Gerbino, M., \& Pastorelli, C. (2015). Why and how to promote adolescents' prosocial behaviors: Direct, mediated and moderated effects of the CEPIDEA school-based program. Journal of Youth Adolescence, 44, $2211-2229$. https://doi.org/10.1007/s10964-015-0293-1 
Carr, E. G., Horner, R. H., Turnbull, A. P., Marquis, J. G., Magito-McLaughlan, D., McAtee, M. L...\& Dolabh, A. (1999). Positive behavior support for people with developmental disabilities: A research synthesis. American Association on Mental Retardation. Washington, DC.

Chandler, L. K., \& Dahlquist, C. M. (2014). Functional assessment: Strategies to prevent and remediate challenging behavior in school settings. Pearson Higher Ed.

Coie, J. D., \& Dodge, K. A. (1998). Aggression and antisocial behavior. W. Damon \& N. Eisenberg, (Ed.), Handbook of child psychology: Social, emotional, and personality development (5. baskı içinde s. 779-862). New York: John Wiley.

Crone, D. A., Hawken, L. S., \& Horner, R. H. (2010). Responding to problem behavior in schools: The behavior education program. New York, NY: Guilford.

Çetin, Y. (2002). Ilköğretim birinci aşama sınıf öğretmenlerinin sınıfta gözlemledikleri disiplin problemleri. (Yayımlanmamış yüksek lisans tezi). Çukurova Üniversitesi, Sosyal Bilimler Enstitüsü, Adana.

Demiroğlu, A. (2001). Ilköğretim okulları birinci kademede sınıf düzeninin sağlanmasında öğretmen özelliklerinin etkisi. (Yayınlanmamış yüksek lisans tezi). Marmara Üniversitesi, Eğitim Bilimleri Enstitüsü, İstanbul.

Danaoğlu, G. (2009). Sınıf ve branş öğretmenlerinin ilköğretim 5. sınıflarda karşılaştıkları istenmeyen davranışlar ve bu davranışlarla baş etme stratejileri. (Yayımlanmamış yüksek lisans tezi). Çukurova Üniversitesi, Sosyal Bilimler Enstitüsü, Adana.

Doğru, N., ve Peker, R. (2004). Özsaygı geliştirme programının lise dokuzuncu sınıf öğrencilerinin özsaygı düzeylerine etkisi. Uludağ Üniversitesi Eğitim Fakültesi Dergisi, 7(2), 315-328.

Durulmuş, M. (2018). Bir kamu ilkokulunda öğrencilerin istenmeyen davranışların nedenlerine ve çözümlerine ilişkin durum çalışması. (Yayımlanmamış yüksek lisans tezi). Gazi Üniversitesi, Eğitim bilimleri enstitüsü, Ankara.

Eisenberg, N. (1986). Altruistic emotion, cognition, and behavior. Lawrance Erlbaum Associates: Minnesota Üniversitesi. ISBN: 0898596246, 9780898596243.

Emmer, E. T., \& Evertson, C. M. (2013). Ilkokul öğretmenleri için sınıf yönetimi. (Çev. Aypay, A.). Ankara: Nobel Akademik Yayıncılık.

Erbaş, D. (2005). Baş makale: Olumlu davranışsal destek. Özel Eğitim Dergisi, 6(1), 1-18.

Erdoğan, i. (2002). Sınıf yönetimi. İstanbul: Sistem Yay.

Eripek, S. (1980). Ankara il merkezinde bulunan ortaöğretim kurumlarında disiplin uygulamaları ve bu uygulamaların öğrencilerin uyum sorunları yönünden değerlendirilmesi. (Yayımlanmamış doktora tezi). Ankara Üniversitesi, Sosyal Bilimleri Enstitüsü, Ankara.

Gündoğdu, R. ve ızgar, H. (2010). Yaratıcı drama temelli çatışma çözme programının ergenlerin çatışma çözme becerisine etkisi. Selçuk Üniversitesi Ahmet Keleşoğlu Eğitim Fakültesi Dergisi, 30, 81-100.

Gündoğdu, S. (2013). ilkokul ve ortaokul öğrencilerinin sınıf yönetiminde istenmeyen öğrenci davranışlarına ilişkin görüşleri ve bu davranışlara karşı uyguladıkları strateji. (Yayımlanmamış yüksek lisans tezi). Hasan Kalyoncu Üniversitesi, Sosyal Bilimler Enstitüsü, Gaziantep.

Hastunç, Y. (2018). Motivasyonel görüşme ilkelerine göre hazırlanmıs psikoeğitim programının ortaokul öğrencilerinin okul tükenmişliği ve yabancılaşma düzeylerine etkisi. (Yayımlanmamış doktora tezi). Yüzüncü Yıl Üniversitesi, Eğitim Bilimleri Enstitüsü, Van.

Hayes, L. (2007). Problem behaviours in early primary school children: Australian normative data using the strengths and difficulties questionnaire. Australian and New Zealand Journal of Psychiatry, 4(3), 231-238. https://doi.org/10.1080\%2F00048670601172715.

Ilgar, L. (2005). Eğitim yönetimi, okul yönetimi, sınıf yönetimi, İstanbul: Beta Basım Dağıtım.

İkiz, F. E., ve Gül, D. (2017). Uyum arttırma grup rehberliğinin ergenlerin sosyal kaygı ve duygusal öz-yeterlik düzeylerine etkisi. Electronic Turkish Studies, 12(18), 361-374.

Neyişçi-Karakaş, B. (2005). ilköğretim birinci kademe öğrencilerinde gözlenen istemeyen davranışlar ve öğretmenlerin bunlarla başa çıkma yöntemleri. (Yayımlanmamış yüksek lisans tezi). Celal Bayar Üniversitesi, Sosyal Bilimler Enstitüsü, Manisa.

Keskin, M. A. (2002). Sınıf öğretmenlerinin karşılaştıkları istenmeyen öğrenci davranışları ve kullandıkları bas etme yolları. (Yayımlanmamış yüksek lisans tezi). Hacettepe Üniversitesi, Sosyal Bilimler Enstitüsü, Ankara.

Kılıçoğlu, C .(2015). Sınıf içerisinde istenmeyen davranışlara karşı öğretmenlerin baş edebilme yöntem ve teknikleri. (Yüksek lisans tezi). Toros Üniversitesi, Sosyal Bilimler Enstitüsü, Mersin.

Kocabey, A. (2008). 2005 Illköğretim programının uygulanması sırasında sınıf öğretmenlerinin sınıfta karşılaştıkları istenmeyen öğrenci davranışları. (Yayımlanmamış yüksek lisans tezi). Çukurova Üniversitesi, Sosyal Bilimleri Enstitüsü, Adana.

Low, S., Polanin, J., \& Espelage, D. (2013). The role of social networks in physical and relational aggression among young adolescents. Journal of Youth and Adolescence, 42,1078-1089. https://doi.org/10.1007/s10964-013-9933-5.

Öz, F. S. (2008). Öfke yönetimi eğitiminin ergenlerde öfke ile başa çıkma ve iletişim becerilerine etkisi. (Yayımlanmamış doktora tezi). Dokuz Eylül Üniversitesi, Eğitim Bilimleri Enstitüsü, İzmir.

Öz, Y. (2018). ilkokul ortaokul ve lisede matematik derslerinde karşılaşılan istenmeyen davranışlar ve öğretmenlerin bu davranışlarla baş etme stratejileri - Erzurum merkez örneği. (Yayımlanmamış yüksek lisans tezi). Atatürk üniversitesi, Eğitim Bilimleri Enstitüsü, Erzurum.

Öztürk, B. (2002). Sınıfta istenmeyen davranışların önlenmesi ve giderilmesi. Ankara: Pegem Yayıncılık.

Öztürk, N. (2001). Sınıf öğretmenlerinin istenmeyen öğrenci davranışlarına ilişkin görüşleri. (Yayımlanmamış yüksek lisans tezi). Hacettepe Üniversitesi, Sosyal Bilimler Enstitüsü, Ankara.

Pala, A. (2005). Sınıfta istenmeyen öğrenci davranışlarını önlemeye dönük disiplin modelleri. Manas Üniversitesi Sosyal Bilimler Dergisi, 13, 171-179.

Romi, S., \& Freund, M. (1999). Teachers', students' and parents' attitudes towards disruptive behaviour problems in high school: A case study. Educational Psychology, 19(1), 53-70. https://doi.org/10.1080/0144341990190104. 
Sadık, F. (2000). ilköğretim I. asama sınıf öğretmenlerinin sınıfta gözlemledikleri problem davranışlar. (Yayımlanmamış yüksek lisans tezi). Çukurova Üniversitesi, Sosyal Bilimler Enstitüsü, Adana.

Sadri Damırchı, E. (2014). Barış eğitimi programının yedinci sını öğrencilerinin çatışma çözme ve iletişim becerilerine etkisi. (Yayımlanmamış doktora tezi). Hacettepe Üniversitesi, Eğitim Bilimleri Enstitüsü, Ankara.

Sakallığlu, A. (2014). Ortaokullarda görev yapan branş öğretmenlerinin sınıf içerisinde karşılaştıkları istenmeyen davranışlar ve bunları yönetmede kullandıkları stratejiler. (Yayımlanmamış yüksek lisans tezi). Okan Üniversitesi, Sosyal Bilimler Enstitüsü, İstanbul.

Sayın, N. (2001). Sınıf öğretmenlerinin karşılaştıkları istenmeyen öğrenci davranışları ve bu davranışların nedenlerine ilişkin görüşleri ile istenmeyen davranışları önleme yöntemleri. (Yayımlanmamış yüksek lisans tezi). Anadolu Üniversitesi, Eğitim Bilimleri Enstitüsü, Eskişehir.

Sevici, H. (2015). Ortaokul Türkçe ders kitaplarındaki metinlerin olumlu davranış kazandırma açısından incelenmesi. (Yayımlanmamış yüksek lisans tezi). Atatürk Üniversitesi, Eğitim Bilimleri Enstitüsü. Erzurum.

Şahin, H. (2004). Öfke denetimi eğitiminin çocuklarda gözlenen saldırgan davranışlar üzerindeki etkisi. (Yayımlanmamış doktora tezi). Hacettepe Üniversitesi, Sosyal Bilimler Enstitüsü. Ankara.

Türkeç, A. (1986). Orta dereceli okullarda öğrencilerde görülen disiplinsiz davranışlar ve bunlara uygulanan yaptırımlar. (Yayımlanmamış yüksek lisans tezi). Ankara Üniversitesi, Sosyal Bilimler Enstitüsü, Ankara.

Türnüklü, A. (2000). Türk ve İngiliz ilköğretim öğretmenlerinin sınıf içi davranış yönetim stratejilerinin karşılaştırılması. Kuram ve Uygulamada Eğitim Yönetimi, 44, 449-465.

Uşaklı, H. (2006). Drama temelli grup rehberliğinin ilköğretim V. sınıf öğrencilerinin arkadaşlık ilişkileri, atılganlık düzeyi ve benlik-saygısına etkisi. (Yayınlanmamış doktora tezi). Dokuz Eylül Üniversitesi, Eğitim Bilimleri Enstitüsü, İzmir.

Uysal, G. (1991). Ortaöğretim kurumlarında disiplin yönetmeliği hükümlerine göre disiplin uygulamalarının değerlendirilmesi. (Yayımlanmamış yüksek lisans tezi). Ankara Üniversitesi, Sosyal Bilimler Enstitüsü, Ankara.

Walker, B., Cheney, D., Stage, S., \& Blum, C. (2005). Schoolwide screening and positive behavior supports: Identifying and supporting students at risk for school failure. Journal of Positive Behavior Interventions, 7(4), 194-204. https://doi.org/10.1177\%2F10983007050070040101.

Weishew, N. L., \& Peng, S. S. (1993). Variables predicting students' problem behaviors. The Journal of Educational Research, 87(1), 5-17. https://doi.org/10.1080/00220671.1993.9941160.

Yüksel, A. (2005). Illköğretim I. kademe 1., 2. ve 3. sınıflarda istenmeyen öğrenci davranışlarına ilişkin öğretmen gözlem ve görüşleri. (Yayımlanmamış yüksek lisans tezi). Afyon Kocatepe Üniversitesi, Sosyal Bilimler Enstitüsü, Afyon. 